\title{
EFFECT OF SOME MULCHING METHODS AS POSSIBLE ALTERNATIVE MEASURES ON BROOMRAPE, ANNUAL WEEDS CONTROL AND PRODUCTIVITY OF TWO FABA BEAN CULTIVARS
}

(Received: 31. 12 .2020)

\author{
By \\ Azza E. Khaffagy, A.R. Morsi" and Maha F. El-Enany \\ Weed Research Central Laboratory and *Food Legume Section, Field Crops Research Institute, \\ Agricultural Research Center, Giza, Egypt.
}

\begin{abstract}
Two field experiments were conducted in a naturally infested field with annual weeds and broomrape (Orobanche crenata Forsk.) at Sakha Agricultural Research Station, Kafr El-Sheikh, Egypt, during 2018/19 and 2019/20 winter seasons. The aims of this work were (1) investigate the performance of two cultivars of faba bean (Giza 843 and Sakha 3) under some weed control treatments [mulching with the rice straw, mulching with the sorghum straw, mulching with the black plastic, mulching with the white plastic, mulching with the blue plastic, stomp extra at rate $1.5 \mathrm{~L} / \mathrm{fed}+$ Round up at rate $75 \mathrm{~cm}^{3} / \mathrm{fed}$, (hand hoeing + hand pulling) twice and untreated check) (2) Effect of some weed control treatments on annual weeds and broomrape, faba bean yield and its components. The results indicated that the cultivar Giza 843 decreased exhibited the lowest dry weight of broad- leaved, grassy and total annual weeds by 27.2, 20.8 and $20.9 \%$, respectively as compared to Sakha 3. It also, decreased broomrape spike length, number of spikes/ plant and dry weight of spikes $/ \mathrm{m}^{2}$ by $30.9,38.5$ and $38.3 \%$, respectively. In addition, it scored the highest values of yield and its components, compared to the cultivar Sakha 3. Moreover, all weed control treatments significantly decreased dry weight of total annual weeds and broomrape, and increased yield components in both seasons. The highest values obtained for faba bean yield (ardab./fed.) yield were detected for mulching with sorghum straw and mulching with black plastic for nine weeks, followed by stomp extra + Round up, mulching with rice straw, mulching with blue plastic and mulching with white by 71.8, 68.9, 67.9, $66.1,64.2$ and $60.9 \%$, respectively compared to the control treatment. The interaction between faba bean cultivars and weed control treatments exerted a significantly integrated impact on annual weeds and broomrape characters which was reflected on increases in yield faba bean and its components. From the results of correlation analysis, the dry weight of total annual weeds and broomrape biomass negatively correlated with faba bean yield and its components. These results indicated that in soil infested with annual weeds and broomrape, it is better to grow the cultivar Giza 843 with the application of weed control treatments such as mulching with the sorghum straw, or mulching with black plastic for nine weeks or stomp extra at rate $1.5 \mathrm{~L} / \mathrm{fed}+$ Round up at rate $75 \mathrm{~cm}^{3} / \mathrm{fed}$. These practices gave the highest reduction in annual weeds and broomrape density and increased faba bean yield and its components and improved faba bean productivity.
\end{abstract}

Key words: Cultivars, mulching, roundup, pendimthalin, Broomrape, faba bean.

\section{INTRODUCTION}

Faba bean (Vicia faba L.) is one of the economically important leguminous crops, with high nutritional value. It is estimated that the seeds have protein content of $25-40 \%$ (Al-Taey et al., 2018), and 56\% carbohydrate, dietary elements, fiber, vitamins, and Fetic acid. Broomrape, a parasitic weed, is a detrimental pest for the cultivation of faba bean in Egypt, which causes significant losses, up to $80 \%$, in the yield of faba bean, and in some cases make farmers stop growing faba bean under heavy infestation conditions. Until now, no single control measure is sufficient by itself to control this parasite in this crop. Thus, a successful strategy for broomrape management, which depends on adoption of integral effects of combination of tolerant faba bean varieties, rationale chemical control measures and suitable cultural 
practices, is very necessary. In Egypt, Gadalla et al. (2010) proved that the cultivar Giza 3 was susceptible and Giza 843 was tolerant to Orobanche infestation, which had the lowest Orobanche spikes/plant. Amer et al. (2012) found significant differences among cultivars in growth, plant height, number branches plant $^{-1}$, pod length and number of seed pod ${ }^{-1}$. Ismail (2013) revealed that faba bean cultivar Misr1 decreased the number and dry weight of Orobanche spikes by 17.3 and $17.0 \%$, respectively, compared with the cultivar Giza 40. On the other hand, many researchers reported that glyphosate application twice at the rate of $178.7 \mathrm{cc} / \mathrm{ha}$ controlled broomrape by $96-99.1 \%$ and increased faba bean seed yield/fed. by 100-149.5 than untreated infested check (El-Metwally et al.,2013; Ismail, 2013 and Eid et al., 2017).

The use of plastic mulching is very popular in many vegetable-growing areas. A nontransparent plastic is used to impede the transmission of photosynthetic radiation through the plastic to the weeds so that the development of weeds is then arrested. The advantages also include better moisture conservation as a reduction in irrigation needs means a reduction in nitrogen leaching, a better soil structure conservation, and an increase in the vegetable yield. Ebaid (1990) found that mulching with polyethylene lowered the number of weeds in faba bean by 54.2-61.4 highest seed yield of faba bean were achieved by application of Stomp (Saad El-Din, 2003 and Hameed and Shahwany, 2017). The effects of Round up on broomrape tubercle is attributable to its selective accumulation in the young parasite plant up to a level of three times as high as that in faba bean host root three days after spraying (Hassanein and Kholosy, 1997).

The aims of this work was to estimate faba bean yield losses, due to broomrape and annual weeds infestation, and to study the effect of mulching methods by plastic (black, white and blue) and plants (rice and sorghum) straw and herbicides on broomrape, annual weeds and productively of two faba bean cultivars under Kafr El-Sheikh Governorate conditions.

\section{MATERIALS AND METHODS}

Two field experiments were conducted in a field with heavily, naturally infested with broomrape in Sakha Agricultural Research Station, Kafr El-Sheikh Governorate during $2018 / 2019$ and 2019/2020 winter seasons to investigate the performance of two faba bean (Vicia faba L.) cultivars under numerous broomrape (Orobanche crenata, Forsk. ) control treatments. Faba bean cultivars (Giza 843 and Sakha 3) were planted on October $25^{\text {th }}$ in both seasons. The mechanical and chemical analyses of the experimental site soil are presented in Table (a) according to Jackson (1967).

Table (a): Some physical and chemical properties of the soils $(0-30 \mathrm{~cm})$, used in two seasons of study.

\begin{tabular}{|l|l|l|l|l|l|l|l|l|l|}
\hline Seasons & $\begin{array}{l}\text { Organic } \\
\text { matter }(\%)\end{array}$ & $\begin{array}{l}\text { pH } \\
\text { soil }\end{array}$ & $\begin{array}{l}\text { Sand } \\
(\%)\end{array}$ & $\begin{array}{l}\text { Silt } \\
(\%)\end{array}$ & $\begin{array}{l}\text { Clay } \\
(\%)\end{array}$ & $\begin{array}{l}\text { Texture } \\
\text { Class }\end{array}$ & $\begin{array}{l}\text { N } \\
\text { Ppm }\end{array}$ & $\begin{array}{l}\text { P } \\
\text { ppm }\end{array}$ & $\begin{array}{l}\text { K } \\
\text { ppm }\end{array}$ \\
\hline $\mathbf{2 0 1 8} / 2019$ & $\mathbf{1 . 3 0}$ & 7.5 & $\mathbf{2 0 . 7}$ & $\mathbf{3 0 . 5}$ & $\mathbf{4 8 . 8}$ & Clay & $\mathbf{3 2 . 0}$ & $\mathbf{2 , 4 2}$ & $\mathbf{2 4 4}$ \\
\hline $\mathbf{2 0 1 9} / 2020$ & $\mathbf{1 . 6 5}$ & $\mathbf{7 . 7}$ & $\mathbf{2 1 . 5 4}$ & $\mathbf{2 8 . 1 6}$ & $\mathbf{5 0 . 3}$ & Clay & $\mathbf{3 3 . 0}$ & $\mathbf{2 . 6 4}$ & $\mathbf{2 4 6}$ \\
\hline
\end{tabular}

plants $/ \mathrm{m}^{2}$, respectively, compared to untreated control (134.0-152.0 plants $\left./ \mathrm{m}^{2}\right)$ and increased crop seed yields by 9.5-9.8 ard./ fed.., respectively, compared to untreated control (6.8-7.0 ard./fed.). Although hand-pulling of broomrape weeds is one of the most used techniques by farmers to control Orobanche, this method is inefficient in highly infested faba bean fields. Indeed, continuous hand pulling of broomrape had slightly increased faba bean yield but not significantly, compared to the control in infested fields sown with a susceptible cultivar at Beja (Kharrat and Halila 1996). Herbicides are the most important available method for annual weeds and Orobanche sp. control. The best control and
A split-plot design in a randomized complete block arrangement was used with four replications. The main plots were allotted to two cultivars and the eight weed control treatments were devoted to sub plots. Each sub plot consists of five ridges of $0.6 \mathrm{~m}$ in width and $3.5 \mathrm{~m}$ length, i.e. the experimental plot area was $10.5 \mathrm{~m}^{2}$. The treatments were as follow:

2.1. Main plots: (Faba bean cultivars)

1- Giza 843 (tolerant to broomrape infection).

2- Sakha 3 (susceptible to broomrape infection).

2.2. Sub plots: (mulching methods and herbicides)

1. Mulching with the rice (Oryza sativa) straw (mulches layer was about $5 \mathrm{~cm}$ ).

2. Mulching with the sorghum (Sorghum ssp.) 
straw (mulches layer was about $5 \mathrm{~cm}$ ).

3. Mulching with black plastic (polyethaline 80 $\mu m$ thickness).

4. Mulching with white plastic (polyethaline 80 $\mu m$ thickness).

5. Mulching with blue plastic (polyethaline 80 $\mu m$ thickness).

6. Stomp extra $45.5 \%$ (pendimthalin) $\mathrm{N}-(1-$ ethylpropyl) $\quad-3,4$ diethyl- 2,6dinitrobenzenamine] at the rate of $1.51 / \mathrm{fed}$ applied after sowing and before irrigation plus hand hoeing at 30 days after sowing and Roundup 48\% WSC (glyphosate) N(phosphonomethyl) glycine, isopropyl ammonium salt at $75 \mathrm{~cm}^{3} / \mathrm{fed}$ (twice) applied at 45 and 60 days after sowing.

7. Hand hoeing twice to annuals weeds at 30 and 50 days after sowing with broomrape hand pulling at 70 and 90 days from sowing.

8. Untreated check (control).

Mulches treatments were carried out by covering with plastic (black, white and blue) and plants rice and sorghum straw were applied before irrigation and after planting faba bean. Plastic mulch was left for 9 weeks after planting and removed carefully after that. Herbicides were sprayed by knapsack sprayer CP3 with water volume of $200 \mathrm{l} / \mathrm{fed}$. In both seasons, calcium super phosphate $\left(15.5 \% \quad \mathrm{P}_{2} \mathrm{O}_{5}\right)$ at the rate of $100 \mathrm{~kg} / \mathrm{fed}$ was added before sowing and ammonium nitrate $(33.5 \% \mathrm{~N})$ at the rate of 50 $\mathrm{kg} / \mathrm{fed}$ was added before the $1^{\text {st }}$ irrigation.

\subsection{Data recorded}

\subsubsection{On annuals weeds}

Weeds were hand pulled at random from one square meter for each plot after 70 and 90 days from sowing and classified into three categories (broadleaved, grassy and total weeds). The dry weight of each group was estimated as $\left(\mathrm{g} / \mathrm{m}^{2}\right)$. Dry weight was determined after drying weeds in a forced draft oven at $70^{\circ} \mathrm{C}$ for 48 hours.

\subsubsection{On broomrape}

Prior faba bean harvesting, broomrape spike length $(\mathrm{cm})$, number of broomrape spikes/plant, number of broomrape spikes $/ \mathrm{m}^{2}$, broomrape dry weight $\left(\mathrm{g} / \mathrm{m}^{2}\right)$, and number of capsules/ broomrape spike were recorded.

\subsubsection{On faba bean yield and its components}

At harvest, samples of ten faba bean plants were collected at random from the central rows of each plot to assess the following criteria: plant height $(\mathrm{cm})$, number of branches/plant, number of pods/plant, weight of pods per plant $(\mathrm{g})$, weight of seeds per plant $(\mathrm{g})$ and 100 -seed weight $(\mathrm{g})$. Seed yield per plot was weighed and adjusted to ardab per feddan.

\subsection{Statistical analysis}

The data were subjected to statistical analysis of split plot design in a randomized complete block arrangement according to procedure outlined by Snedecor and Cochran (1990) and the least significant differences (LSD) value were then computed at 5\% level probability for comparison of the differences between means. Simple correlation matrix was carried out for the two seasons to investigate the relationship between dry weight of broomrape, total weeds and faba bean seed yield and its components according to Steel and Torrie (1980).

\section{RESULTS AND DISCUSSION \\ 3.1. Effect of cultivars \\ 3.1.1. On annuals weeds \\ The dominant weed species in the experimental fields were Chenopodium sp, Sonchus oleraceus L., Ammi majus, Emex spinosus L., Rumex dentatus L., Brassica sp. and Melilotus indica L. as broad-leaved weeds, Avena spp., and Phalaris spp. as grassy weeds and broomrape. The data in Table (1) showed that Giza 843 cultivar reduced significantly the}

Table (1): Effect of faba bean cultivars on dry weight of annual weeds $\left(\mathrm{g} / \mathrm{m}^{2}\right)$ at 70 and 90 days from sowing in 2018/19 and 2019/20 seasons.

\begin{tabular}{|c|c|c|c|c|c|c|}
\hline \multirow{2}{*}{ Cultivars } & \multicolumn{3}{|c|}{$\begin{array}{l}\text { Dry weight of annul weeds }\left(\mathrm{g} / \mathrm{m}^{2}\right) \text { at } 70 \\
\text { days from sowing }\end{array}$} & \multicolumn{3}{|c|}{$\begin{array}{c}\text { Dry weight of annul weeds }\left(\mathrm{g} / \mathrm{m}^{2}\right) \text { at } 90 \\
\text { days from sowing }\end{array}$} \\
\hline & $\begin{array}{c}\text { Grassy } \\
\text { weed }\end{array}$ & $\begin{array}{c}\text { Broad - leaved } \\
\text { weed }\end{array}$ & $\begin{array}{l}\text { Total } \\
\text { weed }\end{array}$ & $\begin{array}{c}\text { Grassy } \\
\text { weed }\end{array}$ & $\begin{array}{l}\text { Broad-leaved } \\
\text { weed }\end{array}$ & $\begin{array}{l}\text { Total } \\
\text { weed }\end{array}$ \\
\hline \multicolumn{7}{|c|}{$2018 / 19$ season } \\
\hline Giza 843 & 57.32 & 53.61 & 110.93 & 99.89 & 52.81 & 152.7 \\
\hline Sakha 3 & 72.32 & 81.68 & 154.00 & 126.1 & 78.93 & 205.0 \\
\hline $\mathbf{L S D}_{0.05}$ & 13.54 & 13.53 & 26.79 & 23.61 & 21.83 & 44.07 \\
\hline \multicolumn{7}{|c|}{$2019 / 20$ season } \\
\hline Giza 843 & 56.60 & 42.63 & 99.23 & 58.68 & 64.00 & 122.7 \\
\hline Sakha 3 & 71.47 & 53.83 & 125.3 & 75.36 & 79.91 & 155.3 \\
\hline LSD $_{0.05}$ & 13.37 & 10.07 & 23.44 & 14.11 & 14.96 & 29.06 \\
\hline
\end{tabular}


dry weight of grassy, broad-leaved and total weeds $\left(\mathrm{g} / \mathrm{m}^{2}\right)$ in both seasons. These results indicated that Giza 843 was more effective than Sakha 3 in reducing the dry weight of grassy, broad-leaved and total weeds by $20.7,34.4$ and $27.9 \%$ after 70 days from sowing and 20.8 , 33.1 and $25.5 \%$, respectively, after 90 days from sowing in the first season.

In the second season, the same cultivar Giza 843 reduced dry grassy, broad-leaved and total weeds by $20.8,20.7$ and $20.8 \%$, after $1^{\text {st }}$ survey, and 22.1, 19.9 and $21.0 \%$, respectively, in second survey compared with Sakha3 cultivar. This result may be due to the strong competition on growth factors such as water, light and nutrients and hence, decreased weeds dry weight. These results were in agreement with those obtained by Gadalla et al. (2010), Amer et al. (2012) and Ismail (2013).

\subsubsection{On broomrape}

Data in Table (2) indicated clearly that the differences between the two studied faba bean cultivars in Orobanche infestation characters reached significance at 5\% level in both $2018 / 2019$ and 2019/2020 seasons. It can be noticed that faba bean cultivar Giza 843 scored the highest reduction percentage in both numbers of broomrape spikes/plant and broomrape spikes $/ \mathrm{m}^{2}$, spike length $(\mathrm{cm})$, broomrape dry weight $\left(\mathrm{g} / \mathrm{m}^{2}\right)$, and number of capsules/broomrape spike (38.6, 38.4, 31.1, 37.5 and $31.0 \%$ ) in 2018/19 winter season and by $38.3,38.2,30,7,41.7,41.6$, and $45.6 \%$, in 2019/20 winter season, respectively, compared to the susceptible cultivar Sakha 3. This may be due to increase in biomass distribution of root system of Giza 843 as their increase in field exudates by faba bean plants, which increase the access of root exudates and consequently increase exudates stimulation for broomrape seed germination. This decrease may be due to the delayed of broomrape attachment to faba bean plants and its delay emergence above soil surface and consequently partially escaped from broomrape injury. These findings are in harmony with those reported by Gadalla et al. (2010).

\subsubsection{On yield and yield components}

Results in Table (3) show that all faba bean cultivars differed significantly in faba bean seed yield per feddan and its components in both 2018/19 and 2019/20 winter seasons. Concerning, the tallest plants of faba bean belonged to cultivar Giza 843 which was taller by 8.2 and $8.1, \%$, respectively, in both seasons compared to cultivar Sakha 3. The highest numbers of branches/plant and pods/plant of faba bean belonged to the cultivar Giza 843 which recorded increase in number of pods/plant by 20.1 and $57.5 \%$ in $2018 / 19$ season and by 24.3 and $65.8 \%$ in $2019 / 20$ season, respectively, as compared to cultivar Sakha 3. The highest weight of pods/plant $(\mathrm{g})$ and weight of seeds/plant $(\mathrm{g})$ of faba bean belonged to the cultivar Giza 843 that gave increases in weight of pods/plant by 53.6, 67.2 $\%$, respectively, and weight seeds/plant (g) by 40.4 and $65.6 \%$ in the $1^{\text {st }}$ and $2^{\text {nd }}$ season, respectively, higher than cultivar Sakha 3. The heaviest 100-seed weight (g) of faba bean belonged to the cultivar Giza 843 which gave increase in weight of 100 -seed by 56.8 and $64.8 \%$ in the $1^{\text {st }}$ and $2^{\text {nd }}$ season, respectively, higher than cultivar Sakha 3. The highest seeds yield/fed of faba bean resulted from the cultivar Giza 843 which gave increases in seed yield (ardab/fed) by 57.3 and $64.5 \%$, in $2018 / 19$ and 2019/20 seasons higher than cultivar Sakha 3. From the previous results depending on Orobanche, severity scale Sakha 3 was considered as highly susceptible cultivar to Orobanche infection. These results proved that Giza 843 is considered tolerant and Sakha 3 was highly susceptible according to the scale

Table (2): Effect of faba bean cultivars on broomrape characters in 2018/19 and 2019/20 seasons.

\begin{tabular}{|c|c|c|c|c|c|}
\hline Cultivars & $\begin{array}{l}\text { Broomrape } \\
\text { spike length } \\
\text { (cm) }\end{array}$ & $\begin{array}{c}\text { No of } \\
\text { broomrape } \\
\text { spikes/plants }\end{array}$ & $\begin{array}{c}\text { No. capsules } \\
\text { /broomrape } \\
\text { spike }\end{array}$ & $\begin{array}{c}\text { Broomrape } \\
\text { dry weight } \\
\left(\mathrm{g} / \mathrm{m}^{2}\right)\end{array}$ & $\begin{array}{c}\text { No of broomrape } \\
\text { spikes } / \mathbf{m}^{2}\end{array}$ \\
\hline & \multicolumn{5}{|c|}{ 2018/19 season } \\
\hline Giza 843 & 46.1 & 4.89 & 23.1 & 42.3 & 24.5 \\
\hline Sakha 3 & 66.9 & 7.97 & 33.5 & 67.7 & 39.8 \\
\hline \multirow[t]{2}{*}{ LSD $_{0.05}$} & 19.6 & 2.65 & 9.85 & 19.6 & 13.3 \\
\hline & \multicolumn{5}{|c|}{ 2019/20 season } \\
\hline Giza 843 & 50.5 & 5.39 & 36.4 & 42.5 & 25.7 \\
\hline Sakha 3 & 72.9 & 8.74 & 66.9 & 72.8 & 41.6 \\
\hline LSD $_{0.05}$ & 20.4 & 2.79 & 18.6 & 17.3 & 13.4 \\
\hline
\end{tabular}


Table (3): Effect of faba bean cultivars on yield and yield components in 2018/19 and 2019/20 seasons.

\begin{tabular}{|l|c|c|c|c|c|c|c|}
\hline Cultivars & $\begin{array}{c}\text { Plant height } \\
\text { (cm) }\end{array}$ & $\begin{array}{c}\text { No of } \\
\text { branches } \\
\text { /plant }\end{array}$ & $\begin{array}{c}\text { No of pods } \\
\text { /plant }\end{array}$ & $\begin{array}{c}\text { weight of } \\
\text { pods } \\
\text { /plant (g) }\end{array}$ & $\begin{array}{c}\text { weight of } \\
\text { seeds } \\
\text { /plant (g) }\end{array}$ & $\begin{array}{c}\text { 100-seed } \\
\text { weight }(\mathbf{g})\end{array}$ & $\begin{array}{c}\text { Seed yield } \\
\text { (ardab/fed.) }\end{array}$ \\
\hline \multicolumn{7}{|c|}{$\mathbf{2 0 1 8 / 1 9}$ season } \\
\hline Giza 843 & 147.1 & 2.69 & 14.25 & 32.49 & 19.12 & 74.97 & 6.07 \\
\hline Sakha 3 & 135.0 & 2.15 & 6.05 & 15.08 & 11.40 & 32.33 & 2.59 \\
\hline LSD $_{\mathbf{0 . 0 5}}$ & 7.16 & 0.13 & 1.63 & 5.01 & 1.73 & 4.43 & 0.66 \\
\hline \multicolumn{7}{|l|}{$\mathbf{2 0 1 9 / 2 0}$ season } \\
\hline Giza 843 & 142.9 & 3.04 & 16.59 & 30.33 & 19.63 & 77.08 & 7.15 \\
\hline Sakha 3 & 131.2 & 2.30 & 5.67 & 9.73 & 6.74 & 27.13 & 2.54 \\
\hline LSD $_{\mathbf{0 . 0 5}}$ & 7.08 & 0.12 & 0.633 & 1.31 & 0.853 & 4.57 & 0.405 \\
\hline
\end{tabular}

suggested by Hassanein et al. (1998) indicated that one Orobanche spike per plant can decrease faba bean seed yield by $15 \%$ and four spikes/ faba bean plant can decrease seed yield by $55 \%$.

\subsection{Effect of mulching methods and} herbicides

\subsubsection{On annual weeds}

Data in Table (4) showed that all of mulching methods and herbicides treatments reduced significantly the dry weight $\left(\mathrm{g} / \mathrm{m}^{2}\right)$ of grassy, broad-leaved and total weeds in both seasons compared with untreated treatment (control). Black plastic for 9 weeks after planting (WAP) and mulching with sorghum straw layer of $5 \mathrm{~cm}$ thickness were the most effective in controlling grassy, broad- leaved, and total weeds; they reduced dry weight of grassy weeds, broad- leaved weeds and total weeds as compared to control treatment by (89.8 and 89.6\%), (91.7 and 91.6\%) and (90.8 and $90.7 \%)$ at 70 days from sowing and $(89.8$ and $89.6 \%)$, (90.9 and $90.7 \%$ ) and (90.4 and $90.2 \%$ ) at 90 days from sowing in the $1^{\text {st }}$ and $2^{\text {nd }}$ seasons, respectively. While, stomp extra $1.5 \mathrm{l} / \mathrm{fed}+$ roundup $75 \mathrm{~cm}^{3} /$ fed herbicides and using of mulching with rice straw layer of $5 \mathrm{~cm}$ thickness caused reduction in dry weight of grassy, broad-leaved and total weeds as compared to control treatment in both seasons by $(89.6,91.6$ and $90.7 \%)$ and $(89.5,90.7$ and $90.1 \%)$, respectively, at $1^{\text {st }}$ survey by $(89.5$, 91.4 and $90.3 \%$ ), and (89.6, 90.7 and $90.2 \%$ ), respectively, at $2^{\text {nd }}$ survey in 2018/19 and 2019/20 season, compared to untreated control. On average, mulching with blue plastic had the lowest dry weight of total weeds at $1^{\text {st }}$ and $2^{\text {nd }}$ survey (85.7 and $85.9 \%$ reduction), followed by mulching with white plastic (74.2 and 73.8 $\%$ ) and hand hoeing + pulling twice (84.6 and $84.4 \%$ ), respectively. The different results may be due to the application of stomp extra, which was highly efficient in controlling grassy and broad weeds. Additionally, black plastic 9 WAP, mulching with sorghum straw and mulching with rice straw were more effective in controlling all annual weeds as compared to the other treatments. Similarly, Mehmood et al. (2018) reported that application of black plastic mulch showed a maximum reduction in weed density, fresh and dry weed biomass and suggested that organic mulches such as dry eucalyptus leaves and wheat or rice straw could be used for effective weed control in corn fields.

\subsubsection{On broomrape}

The data in Table (5) showed that the four mulching methods and the two herbicides treatments significantly reduced the number of broomrape spikes /plant, broomrape spikes $/ \mathrm{m}^{2}$, broomrape spike length $(\mathrm{cm})$, broomrape dry weight $\left(\mathrm{g} / \mathrm{m}^{2}\right)$ and number of capsules /broomrape spike in both seasons as compared with untreated control. Mulching by sorghum straw, black plastic $9 \mathrm{WAP}$ and using by stomp extra $1.5 \mathrm{l} / \mathrm{fed}+$ roundup $75 \mathrm{~cm}^{3} /$ fed herbicides achieved good results in reducing the number of broomrape spikes/plant or per $\mathrm{m}^{2}$ and dry weight of broomrape spikes $/ \mathrm{m}^{2}$. Mulching with sorghum straw reduced the number of broomrape spikes/plant or per $\mathrm{m}^{2}$ and dry weight of broomrape spikes $/ \mathrm{m}^{2}$ by $(88.3,88.7$ and $88.3 \%)$ and (86.6, 86.7 and $85.6 \%$ ) followed by mulching with black plastic 9 WAP by $(86.3,86.8$ and $86.3 \%)$ and (86.3, 86.3 and $85.2 \%) \&$ using by stomp extra 1.5 1/fed + roundup $75 \mathrm{~cm}^{3} /$ fed by $(74.6,75.6$ and $74.6)$ and (72.6, 72.7 and $70.5 \%)$, respectively, in both seasons. The number of capsules/ broomrape spike were gave same direction use mulching sorghum straw and black plastic 9 WAP, with a reduction 88.1 and $85.9 \%$ in 2018/19 season and 85.9 and $86.4 \%$ in 2019/20 season, respectively, compared with untreated control. Moisture was probably trapped under 
Table (4): Effect of mulching methods on dry weight of annual weeds $\left(\mathrm{g} / \mathrm{m}^{2}\right)$ at 70 and 90 days from sowing in $2018 / 19$ and $2019 / 20$ seasons.

\begin{tabular}{|c|c|c|c|c|c|c|}
\hline \multirow[b]{2}{*}{ Mulching methods } & \multicolumn{3}{|c|}{$\begin{array}{c}\text { Dry weight of annual weeds }\left(\mathrm{g} / \mathrm{m}^{2}\right) \\
\text { at } 70 \text { days from sowing }\end{array}$} & \multicolumn{3}{|c|}{$\begin{array}{c}\text { Dry weight of annual weeds }\left(\mathrm{g} / \mathrm{m}^{2}\right) \\
\text { at } 90 \text { days from sowing }\end{array}$} \\
\hline & $\begin{array}{l}\text { Grassy } \\
\text { weeds }\end{array}$ & $\begin{array}{l}\text { Broad- } \\
\text { leaved } \\
\text { weeds }\end{array}$ & $\begin{array}{l}\text { Total } \\
\text { weeds }\end{array}$ & $\begin{array}{c}\text { Grassy } \\
\text { weeds }\end{array}$ & $\begin{array}{l}\text { Broad- } \\
\text { leaved } \\
\text { weeds }\end{array}$ & $\begin{array}{l}\text { Total } \\
\text { weeds }\end{array}$ \\
\hline \multicolumn{7}{|c|}{ 2018/19 season } \\
\hline Mulching with rice straw layer $5 \mathrm{~cm}$ & 29.70 & 27.71 & 57.41 & 51.76 & 27.36 & 79.12 \\
\hline Mulching with sorghum straw layer $5 \mathrm{~cm}$ & 26.63 & 24.84 & 51.47 & 46.41 & 24.53 & 70.95 \\
\hline Mulching with black plastic 9 WAP & 26.25 & 24.49 & 50.74 & 45.74 & 24.18 & 69.93 \\
\hline Mulching with white plastic 9 WAP & 71.69 & 66.88 & 138.57 & 124.93 & 66.05 & 190.9 \\
\hline Mulching with blue plastic 9 WAP & 38.71 & 36.10 & 74.81 & 67.45 & 35.66 & 103.1 \\
\hline Stomp extra $1.5 \mathrm{l} / \mathrm{fed}+$ Roundup $75 \mathrm{~cm}^{3} /$ fed. & 26.67 & 24.88 & 51.56 & 46.48 & 24.57 & 71.06 \\
\hline Hand hoeing twice + Hand pulling twice & 42.82 & 39.94 & 82.76 & 74.61 & 39.45 & 114.06 \\
\hline Untreated check & 256.3 & 296.3 & 552.6 & 446.7 & 285.1 & 731.8 \\
\hline LSD $_{0.05}$ & 26.08 & 23.11 & 49.06 & 45.44 & 22.28 & 65.82 \\
\hline \multicolumn{7}{|c|}{ 2019/20 season } \\
\hline Mulching with rice straw layer $5 \mathrm{~cm}$ & 29.32 & 22.09 & 51.41 & 30.92 & 32.79 & 63.71 \\
\hline Mulching with sorghum straw layer $5 \mathrm{~cm}$ & 26.29 & 19.81 & 46.10 & 27.73 & 29.40 & 57.13 \\
\hline Mulching with black plastic 9 WAP & 25.92 & 19.52 & 45.44 & 27.33 & 28.98 & 56.31 \\
\hline Mulching with white plastic 9 WAP & 70.79 & 53.32 & 124.11 & 74.64 & 79.15 & 153.8 \\
\hline Mulching with blue plastic 9 WAP & 38.22 & 28.78 & 67.00 & 40.30 & 42.73 & 83.03 \\
\hline Stomp extra $1.5 \mathrm{l} / \mathrm{fed}+$ Roundup $75 \mathrm{~cm}^{3} / \mathrm{fed}$. & 26.34 & 19.83 & 46.17 & 27.77 & 29.45 & 57.22 \\
\hline Hand hoeing twice + Hand pulling twice & 42.27 & 31.84 & 74.11 & 44.58 & 47.27 & 91.85 \\
\hline Untreated check & 253.1 & 214.3 & 467.4 & 266.9 & 318.1 & 585.0 \\
\hline LSD $_{0.05}$ & 25.75 & 23.06 & 47.58 & 27.15 & 34.24 & 59.86 \\
\hline
\end{tabular}

Table (5): Effect of mulching methods and herbicides on broomrape characters in 2018/19 and 2019/20 seasons.

\begin{tabular}{|c|c|c|c|c|c|}
\hline Mulching methods & $\begin{array}{c}\text { Broomrape } \\
\text { spike length } \\
(\mathrm{cm})\end{array}$ & $\begin{array}{c}\text { No of } \\
\text { broomrape } \\
\text { spikes/plants }\end{array}$ & $\begin{array}{c}\text { No. capsules } \\
\text { /broomrape } \\
\text { spike }\end{array}$ & $\begin{array}{l}\text { Broomrape } \\
\text { dry weight } \\
\quad\left(\mathrm{g} / \mathrm{m}^{2}\right)\end{array}$ & $\begin{array}{c}\text { No of } \\
\text { broomrape } \\
\text { spikes } / \mathrm{m}^{2}\end{array}$ \\
\hline & \multicolumn{5}{|c|}{ 2018/19 season } \\
\hline Mulching with rice straw layer $5 \mathrm{~cm}$ & 17.56 & 3.97 & 35.11 & 33.99 & 19.86 \\
\hline Mulching with sorghum straw layer $5 \mathrm{~cm}$ & 7.93 & 1.78 & 15.86 & 15.29 & 8.92 \\
\hline Mulching with black plastic 9 WAP & 9.24 & 2.09 & 18.86 & 17.87 & 10.44 \\
\hline Mulching with white plastic 9 WAP & 36.81 & 8.33 & 73.63 & 71.26 & 41.64 \\
\hline Mulching with blue plastic 9 WAP & 27.96 & 6.33 & 55.91 & 54.04 & 31.63 \\
\hline $\begin{array}{l}\text { Stomp extra } 1.5 \mathrm{l} / \mathrm{fed}+\text { Roundup } \\
75 \mathrm{~cm}^{3} / \mathrm{fed} \text {. }\end{array}$ & 17.13 & 3.88 & 34.25 & 33.15 & 19.39 \\
\hline Hand hoeing twice + Hand pulling twice & 42.63 & 9.80 & 85.27 & 83.72 & 49.02 \\
\hline Untreated check & 66.92 & 15.27 & 133.8 & 130.5 & 79.37 \\
\hline \multirow[t]{2}{*}{ LSD $_{0.05}$} & 6.06 & 1.44 & 12.12 & 12.15 & 7.18 \\
\hline & \multicolumn{5}{|c|}{$2019 / 20$ season } \\
\hline Mulching with rice straw layer $5 \mathrm{~cm}$ & 38.02 & 4.33 & 35.04 & 36.25 & 20.53 \\
\hline Mulching with sorghum straw layer $5 \mathrm{~cm}$ & 19.97 & 2.24 & 18.34 & 18.62 & 10.65 \\
\hline Mulching with black plastic 9 WAP & 20.24 & 2.30 & 18.58 & 19.17 & 10.96 \\
\hline Mulching with white plastic 9 WAP & 71.21 & 8.21 & 65.39 & 68.40 & 39.11 \\
\hline Mulching with blue plastic 9 WAP & 65.15 & 7.38 & 59.83 & 61.48 & 35.15 \\
\hline $\begin{array}{l}\text { Stomp extra } 1.5 \mathrm{l} / \mathrm{fed}+\text { Roundup } \\
75 \mathrm{~cm}^{3} / \mathrm{fed} \text {. }\end{array}$ & 40.49 & 4.59 & 37.18 & 38.19 & 21.84 \\
\hline Hand hoeing twice + Hand pulling twice & 92.86 & 10.75 & 85.31 & 89.61 & 51.23 \\
\hline Untreated check & 145.75 & 16.76 & 134.5 & 129.6 & 79.81 \\
\hline LSD $_{0.05}$ & 16.87 & 1.93 & 15.59 & 18.85 & 9.19 \\
\hline
\end{tabular}


the mulch and subsequently the mulch killed the broomrape (Tarara, 2009).

\subsubsection{On yield and yield components}

Data in Table (6) revealed significant differences between weed control treatments for faba bean yield and its components except for plant height $(\mathrm{cm})$ and number of branches /plant $(\mathrm{g})$, where the differences were not significant in both seasons. The highest number of pods/plant was a chivied by shown by using sorghum mulch and black plastic mulch as compared to the untreated control which recorded increase in the number of pods/plant by (69.8 and 66.4) and (58.5 and 55.6\%), in the $1^{\text {st }}$ and $2^{\text {nd }}$ season, respectively, compared to the untreated control. The sorghum straw mulch and black plastic gave increases in weight of and $70.7 \%$, in 2018/19 season and by (67.9 and $67.1 \%$ ), in $2019 / 20$ season compared to untreated control. In this regard, Duppong et al. 2004 reported an increase in plant height when using oat straw mulch than flax and wood straw. It should be noted that, plant residues not only affect on the soil, but also can affect the germination, survival, growth, and competitiveness of weeds and crops. However, the use of mulch can be expensive due to labor costs and other costs associated with mulch preparation. It can be noted that environmentally friendly methods such as the application of plant residues allows long-term environmental durability (Azadbakht et al., 2017).

Table (6): Effect of mulching methods on yield and yield components of faba bean in 2018/19 and 2019/20 seasons.

\begin{tabular}{|c|c|c|c|c|c|c|c|}
\hline Mulching methods & $\begin{array}{c}\text { Plant } \\
\text { height } \\
(\mathbf{c m})\end{array}$ & $\begin{array}{c}\text { No of } \\
\text { branches } \\
\text { /plant }\end{array}$ & $\begin{array}{c}\text { No of } \\
\text { pods } \\
\text { /plant } \\
\end{array}$ & $\begin{array}{l}\text { weight of } \\
\text { pods } \\
\text { /plant (g) }\end{array}$ & $\begin{array}{c}\text { weight of } \\
\text { seeds / } \\
\text { plant (g) }\end{array}$ & $\begin{array}{c}100 \text {-seed } \\
\text { weight } \\
\text { (g) }\end{array}$ & $\begin{array}{r}\text { Seed yield } \\
\text { (ard./fed.) }\end{array}$ \\
\hline \multicolumn{8}{|c|}{ 2018/19 season } \\
\hline Mulching with rice straw layer $5 \mathrm{~cm}$ & 155.4 & 2.62 & 11.22 & 26.53 & 17.65 & 59.93 & 4.87 \\
\hline Mulching with sorghum straw layer $5 \mathrm{~cm}$ & 142.8 & 3.10 & 13.33 & 31.51 & 19.55 & 67.07 & 6.22 \\
\hline Mulching with black plastic 9 WAP & 139.3 & 2.80 & 11.97 & 28.30 & 18.48 & 63.90 & 5.18 \\
\hline Mulching with white plastic 9 WAP & 141.3 & 2.30 & 9.90 & 23.38 & 15.23 & 52.82 & 4.27 \\
\hline Mulching with blue plastic 9 WAP & 142.5 & 2.33 & 10.03 & 2370 & 15.46 & 53.55 & 4.33 \\
\hline Stomp extra $1.5 \mathrm{l} / \mathrm{fed}+$ Roundup $75 \mathrm{~cm}^{3} / \mathrm{fed}$. & 142.4 & 2.67 & 11.45 & 27.07 & 18.15 & 61.15 & 5.03 \\
\hline Hand hoeing twice + Hand pulling twice & 139.3 & 2.15 & 9.27 & 21.85 & 15.82 & 49.37 & 3.22 \\
\hline Untreated check & 125.5 & 1.43 & 4.02 & 9.48 & 8.25 & 21.42 & 1.52 \\
\hline LSD $_{0.05}$ & NS & NS & 1.96 & 4.59 & 2.92 & 9.06 & 0.60 \\
\hline \multicolumn{8}{|c|}{ 2019/20 season } \\
\hline Mulching with rice straw layer $5 \mathrm{~cm}$ & 150,9 & 2.85 & 11.76 & 21.06 & 13.99 & 56.30 & 5.32 \\
\hline Mulching with sorghum straw layer $5 \mathrm{~cm}$ & 138.6 & 3.42 & 14.11 & 25.25 & 16.79 & 64.09 & 6.08 \\
\hline Mulching with black plastic 9 WAP & 135.6 & 3.17 & 13.19 & 23.63 & 15.70 & 61.63 & 5.93 \\
\hline Mulching with white plastic 9 WAP & 137.0 & 2.65 & 11.17 & 20.05 & 12.86 & 51.75 & 4.58 \\
\hline Mulching with blue plastic 9 WAP & 138.3 & 2.75 & 11.67 & 20.05 & 13.88 & 55.85 & 5.33 \\
\hline Stomp extra $1.5 \mathrm{l} / \mathrm{fed}+$ Roundup $75 \mathrm{~cm}^{3} / \mathrm{fed}$. & 138.4 & 3.05 & 12.81 & 22.97 & 15.24 & 61.29 & 5.76 \\
\hline Hand hoeing twice + Hand pulling twice & 135.2 & 2.08 & 8.47 & 15.15 & 10.09 & 40.57 & 3.80 \\
\hline Untreated check & 122.4 & 1.4 & 5.85 & 10.48 & 6.96 & 25.37 & 1.95 \\
\hline LSD $_{0.05}$ & NS & NS & 1.77 & 3.23 & 2.10 & 6.92 & 0.768 \\
\hline
\end{tabular}

pods/plant by (69.9 and $66.0 \%)$ and (58.9 and $55.7 \%$ ), respectively, and weight of seeds/plant (g) by $(69.9$ and $66.0 \%)$ and (58.5 and $55.0 \%)$, respectively, in the $1^{\text {st }}$ and $2^{\text {nd }}$ seasons as compared to untreated control. In addition, using sorghum mulch and black plastic gave an increase in weight of 100 -seed by (68.1 and $66.5 \%$ ) in 2018/19 season and (60.4 and 58.9\%) in 2019/20 season compared to untreated control. Sorghum mulch straw and black plastic gave increases in seed yield (ard./fed.) by 75.6

\subsection{Effect of interaction between cultivars and mulching methods and herbicides \\ 3.3.1. On annual weeds}

The data presented in Table (7) showed that broad-leaved, grassy, and total weeds were affected significantly by the interaction between faba bean cultivars and mulching methods and herbicides treatments. The greatest reduction in total annual weeds was obtained by the interaction between cultivar Giza 843 with black plastic mulch treatment followed by 
sorghum straw mulch, rice straw mulch and herbicides treatment. These results indicated that the highest reduction in dry weight of total weed $(87.9 \%)$ was obtained from mulching with black plastic in first seasons. The results have the same trend in the second season, for Sakha 3 cultivar with the same black plastic mulch. This may be owing to effect of integration between cultivars and black polyethylene film, which gives effective weed control by cutting down solar radiation percentage by more than $90 \%$, resulting in etiolated growth and the eventual death of weeds under the film. These results are in agreement with those obtained by Gadalla et al. (2010).

Table (7): Effect of interaction between faba bean cultivars and mulching methods on dry weight of annual weeds $\left(\mathrm{g} / \mathrm{m}^{2}\right)$ at 70 and 90 days from sowing in $2018 / 19$ and $2019 / 20$ season.

\begin{tabular}{|c|c|c|c|c|c|c|c|}
\hline \multirow{2}{*}{ 恣 } & \multirow[b]{2}{*}{ Mulching methods } & \multicolumn{3}{|c|}{$\begin{array}{l}\text { Dry weight of annual weeds } \\
\left(\mathrm{g} / \mathrm{m}^{2}\right) \text { at } 70 \text { days from sowing }\end{array}$} & \multicolumn{3}{|c|}{$\begin{array}{l}\text { Dry weight of annual weeds } \\
\left(\mathrm{g} / \mathrm{m}^{2}\right) \text { at } 90 \text { days from sowing }\end{array}$} \\
\hline & & $\begin{array}{c}\text { Grassy } \\
\text { weed }\end{array}$ & $\begin{array}{l}\text { Broad- } \\
\text { leaved } \\
\text { weed }\end{array}$ & $\begin{array}{l}\text { Total } \\
\text { weed }\end{array}$ & $\begin{array}{c}\text { Grassy } \\
\text { weed }\end{array}$ & $\begin{array}{l}\text { Broad- } \\
\text { leaved } \\
\text { weed }\end{array}$ & $\begin{array}{l}\text { Total } \\
\text { weed }\end{array}$ \\
\hline \multicolumn{8}{|c|}{ 2018/19 season } \\
\hline \multirow{8}{*}{ 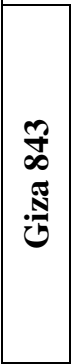 } & Mulching with rice straw layer $5 \mathrm{~cm}$ & 25.48 & 23.83 & 49.32 & 44.41 & 23.48 & 67.89 \\
\hline & Mulching with sorghum straw layer $5 \mathrm{~cm}$ & 25.52 & 23.87 & 49.41 & 44.48 & 23.52 & 68.00 \\
\hline & Mulching with black plastic 9 WAP & 25.12 & 23.49 & 48.62 & 43.78 & 23.15 & 66.92 \\
\hline & Mulching with white plastic 9 WAP & 68.61 & 64.17 & 132.8 & 119.6 & 63.21 & 182.8 \\
\hline & Mulching with blue plastic 9 WAP & 37.04 & 34.64 & 71.68 & 64.55 & 34.13 & 98.67 \\
\hline & Stomp extra $1.5 \mathrm{l} / \mathrm{fed}+$ Roundup $75 \mathrm{~cm}^{3} / \mathrm{fed}$ & 28.42 & 26.58 & 55.00 & 49.53 & 26.19 & 75.72 \\
\hline & Hand hoeing twice + Hand pulling twice & 40.98 & 38.33 & 79.30 & 71.40 & 37.75 & 109.2 \\
\hline & Untreated check & 207.4 & 194.0 & 401.4 & 361.4 & 191.1 & 552.5 \\
\hline \multirow{8}{*}{ 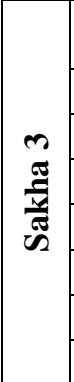 } & Mulching with rice straw layer $5 \mathrm{~cm}$ & 27.78 & 25.85 & 53.63 & 48.41 & 25.59 & 74.00 \\
\hline & Mulching with sorghum straw layer $5 \mathrm{~cm}$ & 27.82 & 25.89 & 53.71 & 48.49 & 25.63 & 74.12 \\
\hline & Mulching with black plastic 9 WAP & 27.38 & 25.48 & 52.86 & 47.72 & 25.23 & 72.94 \\
\hline & Mulching with white plastic 9 WAP & 74.78 & 69.60 & 144.4 & 130.3 & 68.90 & 199.1 \\
\hline & Mulching with blue plastic 9 WAP & 40.37 & 37.57 & 77.94 & 70.35 & 37.19 & 107.5 \\
\hline & Stomp extra $1.5 \mathrm{l} / \mathrm{fed}+$ Roundup $75 \mathrm{~cm}^{3} / \mathrm{fed}$ & 30.98 & 28.83 & 59.81 & 53.99 & 28.54 & 82.53 \\
\hline & Hand hoeing twice + Hand pulling twice & 44.66 & 41.56 & 86.23 & 77.83 & 41.15 & 118.9 \\
\hline & Untreated check & 305.2 & 398.7 & 703.9 & 531.9 & 379.2 & 911.2 \\
\hline \multicolumn{2}{|c|}{ LSD $_{0.05}$} & 36.88 & 32.69 & 69.39 & 64.27 & 31.51 & 93.08 \\
\hline \multicolumn{8}{|c|}{ 2019/20 season } \\
\hline \multirow{8}{*}{ 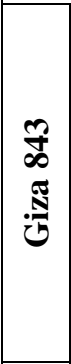 } & Mulching with rice straw layer $5 \mathrm{~cm}$ & 25.20 & 18.98 & 44.19 & 26.57 & 28.18 & 54.76 \\
\hline & Mulching with sorghum straw layer $5 \mathrm{~cm}$ & 25.16 & 18.95 & 44.19 & 26.53 & 28.13 & 54.67 \\
\hline & Mulching with black plastic 9 WAP & 24.81 & 18.68 & 43.49 & 26.15 & 27.73 & 53.89 \\
\hline & Mulching with white plastic 9 WAP & 67.74 & 51.02 & 118.76 & 71.43 & 75.74 & 147.17 \\
\hline & Mulching with blue plastic 9 WAP & 36.57 & 27.54 & 64.12 & 38.56 & 40.89 & 79.45 \\
\hline & Stomp extra $1.5 \mathrm{l} / \mathrm{fed}+$ Roundup $75 \mathrm{~cm}^{3} / \mathrm{fed}$ & 28.06 & 21.14 & 49.20 & 29.59 & 31.38 & 60.97 \\
\hline & Hand hoeing twice + Hand pulling twice & 40.45 & 30.47 & 70.93 & 42.94 & 45.24 & 87.90 \\
\hline & Untreated check & 204.8 & 154.2 & 359.0 & 215.9 & 228.9 & 444.8 \\
\hline \multirow{8}{*}{$\begin{array}{l}n \\
\frac{\pi}{\pi} \\
\frac{\pi}{\pi} \\
n\end{array}$} & Mulching with rice straw layer $5 \mathrm{~cm}$ & 27.47 & 20.69 & 48.16 & 28.96 & 30.72 & 59.68 \\
\hline & Mulching with sorghum straw layer $5 \mathrm{~cm}$ & 27.43 & 20.66 & 48.09 & 28.92 & 30.67 & 59.59 \\
\hline & Mulching with black plastic 9 WAP & 27.03 & 20.36 & 47.40 & 28.51 & 30.23 & 58.74 \\
\hline & Mulching with white plastic 9 WAP & 73.84 & 55.62 & 129.46 & 77.85 & 82.56 & 160.41 \\
\hline & Mulching with blue plastic 9 WAP & 39.86 & 30.02 & 69.89 & 42.03 & 44.57 & 86.61 \\
\hline & Stomp extra $1.5 \mathrm{l} / \mathrm{fed}+$ Roundup $75 \mathrm{~cm}^{3} / \mathrm{fed}$ & 30.59 & 23.04 & 53.63 & 32.25 & 34.20 & 66.46 \\
\hline & Hand hoeing twice + Hand pulling twice & 44.10 & 33.21 & 77.31 & 46.50 & 49.31 & 95.81 \\
\hline & Untreated check & 301.44 & 227.03 & 528.47 & 317.8 & 337.0 & 654.8 \\
\hline \multicolumn{2}{|c|}{$\mathbf{L S D}_{0.05}$} & 36.42 & 32.61 & 67.29 & 38.39 & 48.42 & 84.66 \\
\hline
\end{tabular}




\subsubsection{On broomrape}

Table (8) showed that the interaction of cultivars and mulching methods and herbicides significantly affected the number of broomrape spikes/plant, broomrape spikes $/ \mathrm{m}^{2}$, broomrape spike length $(\mathrm{cm})$, dry weight $\left(\mathrm{g} / \mathrm{m}^{2}\right)$ and No. capsules /broomrape spike in both seasons. The highest reduction percentage on broomrape characters was obtained when using Giza 843 cultivar and mulching with sorghum straw as compared with the susceptible cultivar Sakha 3. Mulching with sorghum straw, black plastic with 9 WAP and mulching with rice straw achieved large reduction in number broomrape spikes/ plant or per $\mathrm{m}^{2}$ and dry weight of broomrape spikes $\left(\mathrm{gm}^{2}\right)$ by $(86.9,86.6$ and 82.8 $\%)$ and $(79.9,80.7$ and $65.0 \%)$, respectively, in the first season.

The results have the same trend, in the second season. No. of capsules /broomrape spike gave the same direction using mulching by sorghum straw and black plastic 9 WAP ( 88.1 and $85.9 \%$ reduction, respectively) in the first season. Soil moisture was probably trapped under the mulch and subsequently mulch killed the broomrape. This may be due to increases in biomass of root system of faba bean plants, which increase the access of root exudates and

Table (8): Effect of interaction between faba bean cultivars and mulching methods on broomrape characters in 2018/19 and 2019/20 seasons.

\begin{tabular}{|c|c|c|c|c|c|c|}
\hline 㟒 & Mulching methods & $\begin{array}{c}\text { Broomrape } \\
\text { spike length } \\
(\mathrm{cm})\end{array}$ & $\begin{array}{c}\text { No of } \\
\text { broomrape } \\
\text { spikes/plants }\end{array}$ & $\begin{array}{c}\text { No of } \\
\text { broomrape } \\
\text { spikes } / \mathbf{m}^{2}\end{array}$ & $\begin{array}{l}\text { Broomrape } \\
\text { dry weight } \\
\quad\left(g / \mathbf{m}^{2}\right)\end{array}$ & $\begin{array}{c}\text { No. } \\
\text { capsules } \\
\text { /broomrape } \\
\text { spike }\end{array}$ \\
\hline \multicolumn{7}{|c|}{ 2018/19 season } \\
\hline \multirow{8}{*}{ 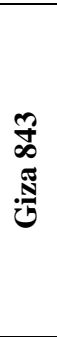 } & Mulching with rice straw layer $5 \mathrm{~cm}$ & 31.79 & 3.37 & 16.87 & 29.17 & 15.89 \\
\hline & Mulching with sorghum straw layer $5 \mathrm{~cm}$ & 15.74 & 1.67 & 8.33 & 14.44 & 7.87 \\
\hline & Mulching with black plastic 9 WAP & 17.39 & 1.85 & 9.23 & 15.96 & 8.69 \\
\hline & Mulching with white plastic 9 WAP & 67.20 & 7.13 & 35.67 & 61.65 & 33.60 \\
\hline & Mulching with blue plastic 9 WAP & 51.97 & 5.53 & 27.67 & 47.69 & 25.99 \\
\hline & Stomp extra $1.5 \mathrm{l} / \mathrm{fed}+$ Roundup $75 \mathrm{~cm}^{3} / \mathrm{fed}$. & 31.31 & 3.33 & 16.67 & 28.72 & 15.65 \\
\hline & Hand hoeing twice + Hand pulling twice & 52.15 & 5.53 & 27.63 & 47.85 & 26.08 \\
\hline & Untreated check & 101.3 & 10.76 & 53.80 & 92.95 & 50.66 \\
\hline \multirow{8}{*}{ 章 } & Mulching with rice straw layer $5 \mathrm{~cm}$ & 38.43 & 4.57 & \multirow{2}{*}{$\begin{array}{c}22.85 \\
9.51\end{array}$} & 38.82 & 19.22 \\
\hline & Mulching with sorghum straw layer $5 \mathrm{~cm}$ & 15.99 & 1.90 & & 16.15 & 7.99 \\
\hline & Mulching with black plastic 9 WAP & 19.58 & 2.33 & 11.64 & 19.78 & 9.79 \\
\hline & Mulching with white plastic 9 WAP & 80.05 & 9.52 & 47.61 & 80.86 & 40.03 \\
\hline & Mulching with blue plastic 9 WAP & 59.86 & 7.12 & 35.59 & 60.46 & 29.93 \\
\hline & Stomp extra $1.5 \mathrm{l} / \mathrm{fed}+$ Roundup $75 \mathrm{~cm}^{3} / \mathrm{fed}$. & 37.19 & 4.42 & 22.12 & 37.57 & 18.60 \\
\hline & Hand hoeing twice + Hand pulling twice & 118.4 & 14.08 & 70.41 & 119.6 & 59.19 \\
\hline & Untreated check & 166.4 & 19.79 & 98.93 & 168.0 & 83.18 \\
\hline \multicolumn{2}{|c|}{ LSD $_{0.05}$} & 16.77 & 1.98 & 9.93 & 16.82 & 8.39 \\
\hline \multicolumn{7}{|c|}{ 2019/20 season } \\
\hline \multirow{8}{*}{ 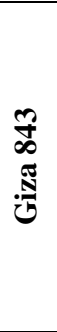 } & Mulching with rice straw layer $5 \mathrm{~cm}$ & 34.18 & 17.18 & 18.98 & 30.72 & 31.65 \\
\hline & Mulching with sorghum straw layer $5 \mathrm{~cm}$ & 22.53 & 11.36 & 18.95 & 19.86 & 20.69 \\
\hline & Mulching with black plastic 9 WAP & 19.15 & 9.76 & 18.68 & 17.06 & 17.59 \\
\hline & Mulching with white plastic 9 WAP & 55.23 & 28.46 & 51.02 & 49.78 & 50.72 \\
\hline & Mulching with blue plastic 9 WAP & 65.12 & 33.09 & 27.54 & 57.89 & 59.79 \\
\hline & Stomp extra $1.5 \mathrm{l} / \mathrm{fed}+$ Roundup $75 \mathrm{~cm}^{3} / \mathrm{fed}$. & 40.47 & 20.55 & 21.14 & 35.95 & 37.17 \\
\hline & Hand hoeing twice + Hand pulling twice & 56.79 & 28.88 & 30.47 & 50.51 & 52.15 \\
\hline & Untreated check & 110.3 & 56.22 & 154.2 & 78.32 & 101.3 \\
\hline \multirow{8}{*}{$\underset{\frac{\pi}{\pi}}{\frac{\pi}{\pi}}$} & Mulching with rice straw layer $5 \mathrm{~cm}$ & 41.85 & 23.88 & 20.69 & 41.77 & 38.43 \\
\hline & Mulching with sorghum straw layer $5 \mathrm{~cm}$ & 17.41 & 9.93 & 20.66 & 17.38 & 15.99 \\
\hline & Mulching with black plastic 9 WAP & 21.31 & 12.17 & 20.36 & 21.28 & 15.58 \\
\hline & Mulching with white plastic 9 WAP & 87.18 & 49.75 & 55.62 & 87.02 & 80.05 \\
\hline & Mulching with blue plastic 9 WAP & 65.19 & 37.19 & 30.02 & 65.07 & 59.86 \\
\hline & Stomp extra $1.5 \mathrm{l} / \mathrm{fed}+$ Roundup $75 \mathrm{~cm}^{3} / \mathrm{fed}$. & 40.51 & 23.12 & 23.04 & 40.43 & 37.19 \\
\hline & Hand hoeing twice + Hand pulling twice & 128.9 & 73.57 & 33.21 & 128.7 & 118.4 \\
\hline & Untreated check & 181.2 & 103.4 & 227.03 & 180.8 & 166.4 \\
\hline \multicolumn{2}{|c|}{ LSD $_{0.05}$} & 23.35 & 12.72 & 2.67 & 26.09 & 21.45 \\
\hline
\end{tabular}


consequently increase exudates stimulation for broomrape seed germination.

\subsubsection{On yield and yield components}

Data presented in Table (9) showed that the effect of interaction between cultivars and mulching methods and herbicides on yield and yield components was statistically significant at $5 \%$ level in 2018/19 and 2019/20 seasons. The highest number of pods/plant of faba bean was obtained from the cultivar Giza 843 when using sorghum straw mulch, which increased by 36.7 and $23.4 \%$ in $2018 / 19$ season and by 42 and $24.7 \%$ in 2019/ 20 season compared over cultivar Sakha 3, respectively. Table (9) shows that the package which consist of planting Giza 843 cultivar with sorghum straw mulch gave the highest values of weight of pods/plant $(\mathrm{g})$ and weight of seeds/plant ( $\mathrm{g}$ ) in both seasons, as compared with untreated Sakha 3 which gave the lowest values of $16.9,6.0(\mathrm{~g})$ in $2018 / 19$ and $10.4,20.5(\mathrm{~g})$ in 2019/20 season. The highest yield of seeds (ard./fed.) (Fig. 1) was obtained from Giza 843 cultivar with sorghum straw mulch and spraying Roundup twice at the rate of $75 \mathrm{~cm}^{3} / \mathrm{fed}$ which increased by 8.97 and

Table (9): Effect of interaction between faba bean cultivars and mulching methods on yield and yield components in 2018/19 and 2019/20 seasons.

\begin{tabular}{|c|c|c|c|c|c|c|}
\hline$\stackrel{\stackrel{\mathscr{n}}{E}}{\stackrel{\Xi}{E}}$ & Mulching methods & $\begin{array}{l}\text { No of } \\
\text { pods } \\
\text { /plant }\end{array}$ & $\begin{array}{l}\text { weight of } \\
\text { pods } \\
\text { /plant (g) }\end{array}$ & $\begin{array}{c}\text { weight of } \\
\text { seeds } \\
\text { /plant (g) }\end{array}$ & $\begin{array}{c}\text { 100-seed } \\
\text { weight } \\
\text { (g) }\end{array}$ & $\begin{array}{c}\text { Seed } \\
\text { yield } \\
\text { (ardab } \\
\text { /fed.) }\end{array}$ \\
\hline \multirow{9}{*}{$\begin{array}{l}\text { ? } \\
\text { : } \\
\text { : }\end{array}$} & \multicolumn{6}{|c|}{ 2018/19 season } \\
\hline & Mulching with rice straw layer $5 \mathrm{~cm}$ & 14.73 & 39.90 & 19.70 & 83.93 & 6.77 \\
\hline & Mulching with sorghum straw layer $5 \mathrm{~cm}$ & 16.80 & 46.30 & 21.93 & 92.00 & 8.97 \\
\hline & Mulching with black plastic 9 WAP & 15.63 & 39.60 & 19.67 & 88.73 & 7.23 \\
\hline & Mulching with white plastic 9 WAP & 12.93 & 31.53 & 16.77 & 74.30 & 6.00 \\
\hline & Mulching with blue plastic 9 WAP & 13.10 & 32.07 & 16.97 & 75.27 & 6.07 \\
\hline & Stomp extra $1.5 \mathrm{l} / \mathrm{fed}+$ Roundup $75 \mathrm{~cm}^{3} / \mathrm{fed}$. & 15.10 & 37.97 & 19.10 & 85.83 & 7.00 \\
\hline & Hand hoeing twice + Hand pulling twice & 12.03 & 28.83 & 15.83 & 69.47 & 4.57 \\
\hline & Untreated check & 4.57 & 6.90 & 8.00 & 30.23 & 1.93 \\
\hline \multirow{8}{*}{$\frac{\mathscr{T}}{\frac{\pi}{\pi}}$} & Mulching with rice straw layer $5 \mathrm{~cm}$ & 5.70 & 16.83 & 9.10 & 35.93 & 2.97 \\
\hline & Mulching with sorghum straw layer $5 \mathrm{~cm}$ & 6.87 & 19.73 & 10.33 & 42.13 & 3.97 \\
\hline & Mulching with black plastic 9 WAP & 6.30 & 18.30 & 9.77 & 39.07 & 3.47 \\
\hline & Mulching with white plastic 9 WAP & 4.87 & 14.70 & 8.20 & 31.33 & 3.13 \\
\hline & Mulching with blue plastic 9 WAP & 4.97 & 14.93 & 8.30 & 31.83 & 2.53 \\
\hline & Stomp extra $1.5 \mathrm{l} / \mathrm{fed}+$ Roundup $75 \mathrm{~cm}^{3} / \mathrm{fed}$. & 5.80 & 17.07 & 9.20 & 36.47 & 2.60 \\
\hline & Hand hoeing twice + Hand pulling twice & 4.50 & 13.73 & 7.80 & 29.27 & 3.07 \\
\hline & Untreated check & 1.73 & 5.93 & 4.50 & 12.60 & 1.87 \\
\hline \multicolumn{2}{|c|}{$\mathbf{L S D}_{0.05}$} & 2.71 & 8.09 & 2.88 & 12.54 & 0.836 \\
\hline \multicolumn{7}{|c|}{ 2019/20 season } \\
\hline \multirow{8}{*}{ 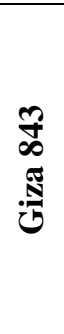 } & Mulching with rice straw layer $5 \mathrm{~cm}$ & 16.29 & 35.79 & 20.57 & 82.77 & 7.80 \\
\hline & Mulching with sorghum straw layer $5 \mathrm{~cm}$ & 19.75 & 42.95 & 24.69 & 92.33 & 8.80 \\
\hline & Mulching with black plastic 9 WAP & 18.65 & 40.69 & 23.39 & 91.06 & 8.83 \\
\hline & Mulching with white plastic 9 WAP & 15.65 & 35.04 & 19.32 & 77.75 & 7.00 \\
\hline & Mulching with blue plastic 9 WAP & 16.83 & 36.92 & 21.22 & 85.39 & 8.03 \\
\hline & Stomp extra $1.5 \mathrm{l} / \mathrm{fed}+$ Roundup $75 \mathrm{~cm}^{3} / \mathrm{fed}$. & 18.29 & 39.93 & 22.95 & 92.35 & 8.67 \\
\hline & Hand hoeing twice + Hand pulling twice & 11.19 & 25.24 & 14.51 & 58.38 & 5.46 \\
\hline & Untreated check & 7.73 & 18.08 & 10.4 & 36.60 & 2.60 \\
\hline \multirow{8}{*}{ 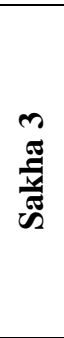 } & Mulching with rice straw layer $5 \mathrm{~cm}$ & 6.23 & 12.9 & 7.41 & 29.83 & 2.83 \\
\hline & Mulching with sorghum straw layer $5 \mathrm{~cm}$ & 7.46 & 15.44 & 8.88 & 35.85 & 3.36 \\
\hline & Mulching with black plastic 9 WAP & 6.72 & 13.92 & 8.00 & 32.19 & 3.03 \\
\hline & Mulching with white plastic 9 WAP & 5.41 & 11.20 & 6.40 & 25.74 & 2.17 \\
\hline & Mulching with blue plastic 9 WAP & 5.49 & 11.37 & 6.54 & 26.30 & 2.63 \\
\hline & Stomp extra $1.5 \mathrm{l} / \mathrm{fed}+$ Roundup $75 \mathrm{~cm}^{3} / \mathrm{fed}$. & 6.31 & 13.07 & 7.51 & 30.23 & 2.87 \\
\hline & Hand hoeing twice + Hand pulling twice & 4.75 & 9.84 & 5.66 & 22.76 & 2.1 \\
\hline & Untreated check & 2.95 & 6.11 & 3.51 & 14.13 & 1.3 \\
\hline \multicolumn{2}{|c|}{ LSD $_{0.05}$} & 2.46 & 5.09 & 2.91 & 9.57 & 1.06 \\
\hline
\end{tabular}




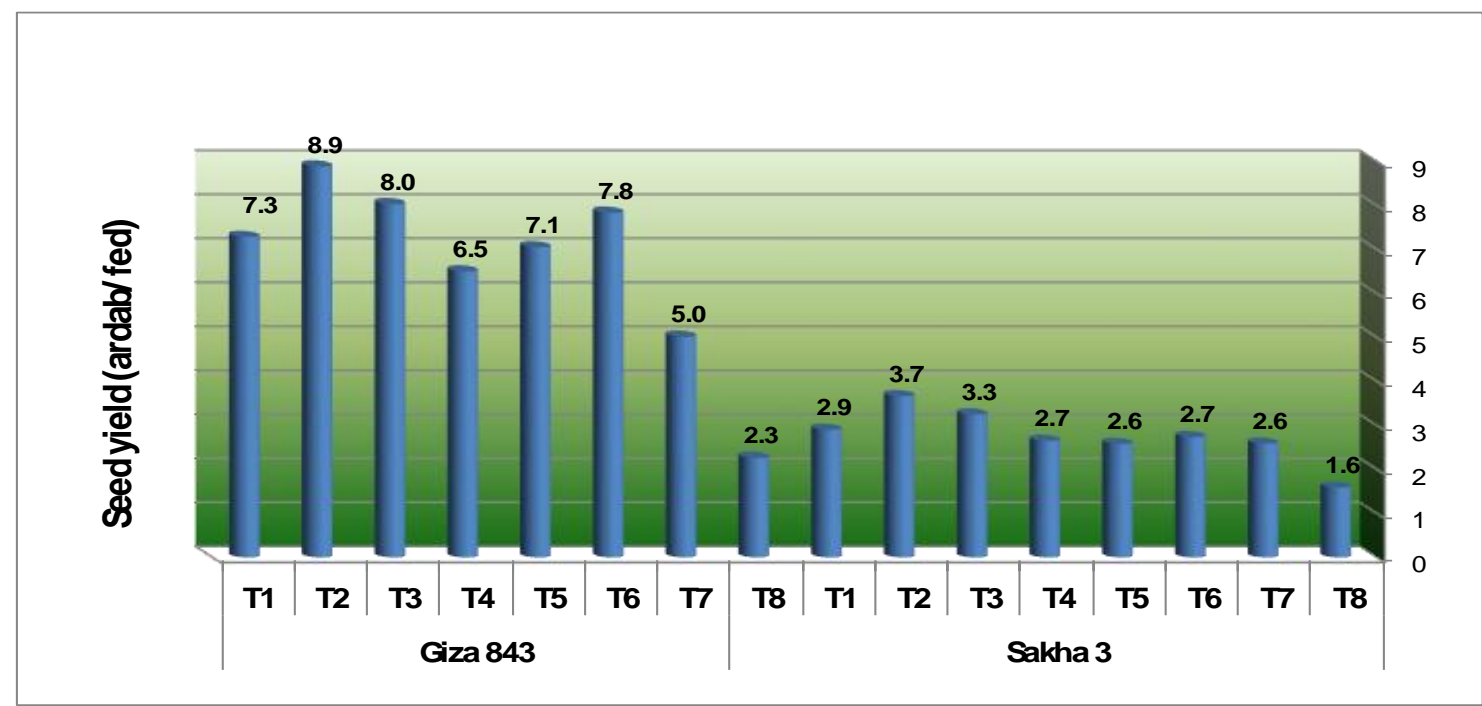

T1 mulching with rice straw layer $5 \mathrm{~cm}$. T2 mulching with sorghum straw layer $5 \mathrm{~cm}$. T3 mulching with black plastic 9 WAP. T4 mulching with white plastic 9 WAP.
T5 mulching with blue plastic 9 WAP.

T6 stomp extra at rate $1.5 \mathrm{~L} / \mathrm{fed}+$ Round up at rate $75 \mathrm{~cm}^{3} / \mathrm{fed}$.

T7 Hand hoeing twice + hand pulling twice

T8 untreated check (control).

Fig. (1): Effect of interaction between faba bean cultivars and mulching methods on seed yield.

7.0 ardab/fed., in both seasons, respectively as compared with untreated Sakha 3 cultivar in 2018/19 and by 8.80, 8,67 ard./fed, 2019/20 season, respectively as compared with untreated Sakha 3. Similarly, the hundred seed weight is also increased compared to untreated, but remains the same between the different types of mulch. The results obtained are in agreement with those obtained by Hassanein and Kholosy (1997) and Gadalla et al. (2010).

\subsubsection{Correlation among studied characters and faba bean yield}

Data presented in Table (10) indicated clearly that simple correlation coefficients between dry weight of broadleaf, grassy, total weeds, No of broomrape spikes /plant or per $\mathrm{m}^{2}$, No. of capsules /broomrape spike and dry weight of broomrape spikes $/ \mathrm{m}^{2}$ and faba bean yield were statistically significant strong negative at 5\% level. This means that number of broomrape spikes/ plant or $\mathrm{m}^{2}$ and dry weight of broomrape spikes $/ \mathrm{m}^{2}$ were more aggressive in their parasitism to seed yield (ard./fed.) of faba bean. In addition, correlation analysis revealed that the yield increases were positively contributed to the increases in No. of pods/plant, weight of pods/plant, 100-seed weight and seed yield (ard./fed.). Hence,

Table (10): Correlation coefficient analysis among all studied characters faba bean, broomrape and annual weeds.

\begin{tabular}{|c|c|c|c|c|c|c|c|c|c|c|c|c|}
\hline Characters & $\begin{array}{c}\text { Broad- } \\
\text { leaved } \\
\text { weed }\end{array}$ & $\begin{array}{l}\text { Total } \\
\text { weed }\end{array}$ & $\begin{array}{c}\text { Broomra } \\
\text { pe spike } \\
\text { length } \\
(\mathrm{cm})\end{array}$ & $\begin{array}{c}\begin{array}{c}\text { No of } \\
\text { broomrape } \\
\text { spikes/ } \\
\text { plants }\end{array} \\
\end{array}$ & $\begin{array}{c}\text { No of } \\
\text { broomrape } \\
\text { spikes } / \mathbf{m}^{2}\end{array}$ & $\begin{array}{c}\text { Broomra } \\
\text { pe dry } \\
\text { weight } \\
\left(\mathrm{g} / \mathbf{m}^{2}\right)\end{array}$ & \begin{tabular}{|c|} 
No. \\
capsules \\
/broomra \\
pe spike
\end{tabular} & $\begin{array}{c}\text { No of } \\
\text { pods } \\
\text { /plant }\end{array}$ & $\begin{array}{c}\begin{array}{c}\text { weight } \\
\text { of pods } \\
\text { /plant } \\
\text { (g) }\end{array} \\
\end{array}$ & $\begin{array}{l}\text { weight of } \\
\text { seeds } \\
\text { /plant (g) }\end{array}$ & $\begin{array}{c}\begin{array}{c}100- \\
\text { seed } \\
\text { weight } \\
(\mathrm{g})\end{array} \\
\end{array}$ & $\begin{array}{c}\text { Seed } \\
\text { yield } \\
\text { (ardab/ } \\
\text { fed.) }\end{array}$ \\
\hline Grassy weed & $.995 * *$ & $.999 * *$ & $.789 * *$ & $.776 * *$ & $.776^{* *}$ & $.749 * *$ & $.787 * *$ & $-.421 * *$ & $-.431 * *$ & $-.420 * *$ & $-.442 * *$ & $-.464 * *$ \\
\hline broad-leaved weed & & $.999 * *$ & $.796^{* *}$ & $.787 * *$ & $.787 * *$ & $.764 * *$ & $.794 * *$ & $-.425 * * \mid$ & $-.435 * *$ & $-.424 * *$ & $-.445^{* *}$ & $-.461 * *$ \\
\hline Total weed & & & $.793 * *$ & $.782 * *$ & $.782 * *$ & $.756^{* *}$ & $.791 * *$ & $-.423 * *$ & $-.433 * *$ & $-.422 * *$ & $-.444 * *$ & $-.463^{* *}$ \\
\hline Broomrape spike length $(\mathrm{cm}$ & & & & $.997 * *$ & $.997 * *$ & $.990 * *$ & $1.000 * *$ & $-.536 * *$ & $-.543 * *$ & $-.535 * *$ & $-.550 * *$ & $-.570 * *$ \\
\hline No of broomrape spikes/plants & & & & & $1.000 * *$ & $.995 * *$ & $.996 * *$ & $-.569 * * \mid$ & $-.576 * * \mid$ & $-.569 * *$ & $-.583^{* * *}$ & $-.597 * *$ \\
\hline No of broomrape spikes $/ \mathrm{m}^{2}$ & & & & & & $.995^{* *}$ & $.996 * *$ & $-.569 * *$ & $-.576^{* * *}$ & $-.569 * *$ & $-.583^{* *}$ & $-.598 * *$ \\
\hline Broomrape dry weight $\left(\mathrm{g} / \mathrm{m}^{2}\right)$ & & & & & & & $.990 * *$ & $-.562 * *$ & $-.568 * *$ & $-.562 * *$ & $-.576 * *$ & $-.586 * *$ \\
\hline No. capsules /broomrape spike & & & & & & & & $-.533 * *$ & $-.540 * *$ & $-.532 * *$ & $-.548 * *$ & $-.567 * *$ \\
\hline No of pods /plant & & & & & & & & & $1.000 * *$ & $1.000 * *$ & $.993 * *$ & $.984 * *$ \\
\hline weight of pods /plant (g) & & & & & & & & & & $.999 * *$ & $.993 * *$ & $.983 * *$ \\
\hline weight of seeds /plant (g) & & & & & & & & & & & $.993 * *$ & $.985^{* *}$ \\
\hline 100-seed weight (g) & & & & & & & & & & & & $.988 * *$ \\
\hline
\end{tabular}


mulching methods play a major role in increasing faba bean productivity, if applied at the suitable time, rate, stage of weed growth and control broomrape growth.

\section{Conclusion}

The negative impacts of herbicides on humans, animals, and environment has attracted the attention of researchers to find new environmentally friendly methods for weed control. From the data presented, we conclude that the mulch practice could be one of the possible strategies to reduce the use of herbicides in the faba bean crop, mainly by reducing density and biomass of weed species. Indeed, the weed control efficiency of sorghum straw mulch and black plastic has been around 90.8 and $90.3 \%$ respectively, which allow an improvement in faba bean yield components, therefore, they allowed an increase in faba bean yield (ard./fed.) by 71.8 and $68.9 \%$, as compared to control treatment.

\section{REFERENCES}

Al-Taey D. K. A., Mijwel A. K. and Al-Azawy S. S. (2018). Study efficiency of poultry litter and kinetin in reduced effects of saline water in Vicia faba. Research J. Pharm. Tech., 11(1): 294-300.

Amer N. N. Kakahy, Ahmad D. and Abdullahi A. S. (2012). The effect of planting distance on yield of beans (Vicia faba L.) under drip irrigation system. Afr. J. Agric. Res., 7(46): 6110-6114.

Azadbakht A., Alebrahim M. T. and Ghavidel A. (2017). The effect of chemical and nonchemical control methods on weeds in potato (Solanum tuberosum L.) cultivation in Ardabil province. J. Appl., Sci. Res., 9 (1): 197-204.

Duppong L. M, Delate K., Liebman M., Horton R., Romero F., Kraus G., Petrich J. and Chowdhury P. K. (2004). The Effect of Natural Mulches on Crop Performance, Weed Suppression and Biochemical Constituents of Catnip and St. John's Wort. Crop Sci., 44 (3): 861-869.

Ebaid M. A. (1990). Effect of weed control method and irrigation number on growth and yield of field bean (Vicia faba L.). Ann. Agric. Sci., Moshtohor, 28 (3): 14291439.

Eid S. D. M., Mobarak O. M. M. and AbouZied Kh. A. (2017). Evaluation of Integrated Broomrape (Orobanche crenata) Management Packages under Effect of Varieties, Seeding Rates and Roundup Treatment in Faba Bean under Sandy Soil Conditions. Alex. J. Agric. Sci., 62(1): 31-44.

EL-Metwally I. M, El-Shahawy T. A. and Ahmed M. A. (2013). Effect of sowing dates and some broomrape control treatments on faba bean growth and yield. J. Appl. Sci. Res., 9 (1): 197-204.

Gadalla N. O, Eman, M. Fahmy Bahieldin A., Abd-Elsattar A., Naglaa A. Ashry and Magda A. M. El-Enany (2010). Evaluation of gene expression for Orobanche tolerance in faba bean (Vicia faba L.). J. Genet. Eng. Biotech., 8 (1): 53-63.

Hameed H. and Shahwany A. W. (2017). Allelopathic Interactions of Sunflower Mulch on Growth and Yield of Faba Bean and Mate Weeds. Int'l J. Sci. and Res. (IJSR). ISSN (Online): 2319-7064 Index Copernicus (7), P: 1462-1465.

Hassanein E. E. and Kholosy A. S. (1997). Demonstration plots of faba bean for broomrape control on Fayoum governorate NVRP for wild oats control in wheat and other winter crops. $5^{\text {th }}$ Annual Meeting, Cairo, 11-15 Sept: 109-111.

Hassanein E. E, El-Marsafy H. T., Kholosy A. S. O. and Ibrahim H. M. (1998). Variation in faba bean cultivar in Orobanche infection as measured by different reaction scales. Ann. Agric. Ain Shams Univ., Cairo, Egypt., 43 (1):189-200.

Ismail A. E. A. (2013). Integration between nitrogen, manure fertilizers, cultural practices and glyphosate on broomrape (Orobanche crenata Forsk) control in faba beans (Vicia faba L.). Bull. Fac. Agric. Cairo Univ., 64: 369-378.

Jackson M. L. (1967). In: Soil chemical analysis. $\left(2^{\text {nd }} \mathrm{Ed}\right)$. Prentice Hall of India Private and L.T.D., New Delhi, India.

Kharrat M. and Halila M. H. (1996). Control of Orobanche foetida on vicia faba: comparison between different control measures. P:734-738 in Advances in Parasitic plant Research, (Junta de Andalucia, ed.).

Mehmood T., Khan S., Qayyum A., Gurmani A. R., Ahmed W., Liaquat M. and Farid (2018). Evaluation of Organic and Inorganic Mulching as an Integrated Weed Management Strategy in Maize under rain fed Conditions, Plant a Daninha, 36, 13. 
Saad El-Din S. A. (2003). Efficiency of some weed control treatments on growth, yield and its components of broad bean (Vicia faba L.). Egypt. J. Appl. Sci., 18 (6B) : 586-604.

Snedecor G. W. and Cochran W. E. (1990). In: Statistical Methods. $6^{\text {th }}$ ed. Iowa State Univ. Press, Ames, Iowa, U.S.A.
Steel R. G. D. and Torrie J. H. (1980). In: Principles and Procedures of Statistics. McGraw Hill Book Company Inc., New York, USA, $481 \mathrm{pp}$.

Tarara J. M. (2009). Book Review, Plant Growth and Climate Change. Hort. Sci., 43 (23): 23 - 99.

\title{
تأثير بعض طرق التفطية كبائل ممكنة لمكافحة الهالوك والحشائش الحولية على إنتاجية صنفين من الفول البلاي

$$
\text { عزة السيد خفاجي ـ أكرم رشاد مرسي" - مـها فهيم العناني }
$$

$$
\begin{aligned}
& \text { المعمل المركزي لبحوث الحشائش و* قسم بحوث المحاصيل البقولية ـ معهد بحوث المحاصيل الحقلية } \\
& \text { ـ مركز البحوث الزر اعيةـ الجيزة- مصر. }
\end{aligned}
$$

\begin{abstract}
ملخص
أجريت تجربتان حقليتان في حقول مصابة طبيعيا بالحشائش الحولية والهالوك بمحطة البحوث الزراعية، سخا-

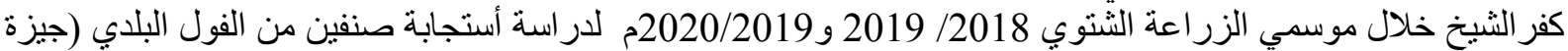

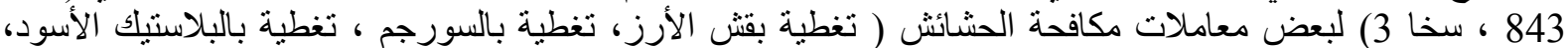

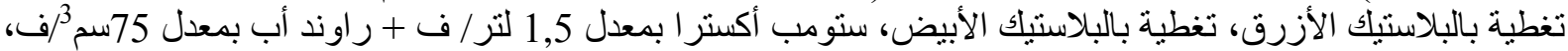

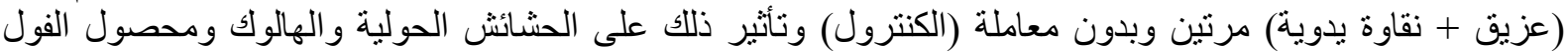
ومكوناته. أوضحت النتائج أن الصنف وبن جيزة 843 أظهر أقل وزن جاثن جاف للحشائش الحولية عريضة و ولية ضيقة الأوراق

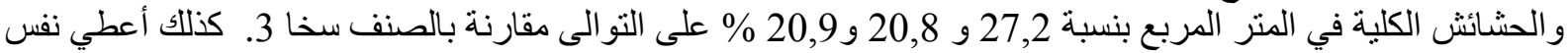

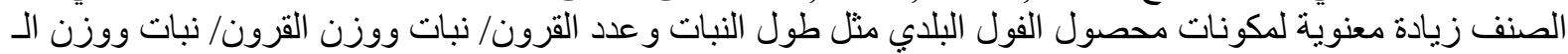

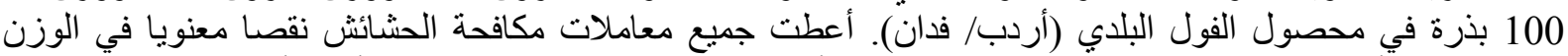

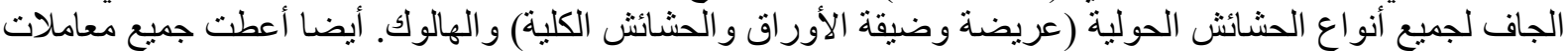

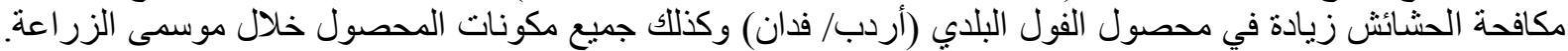

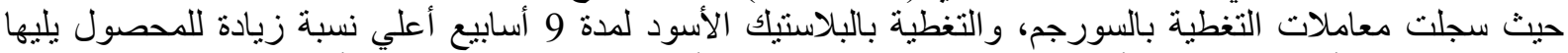

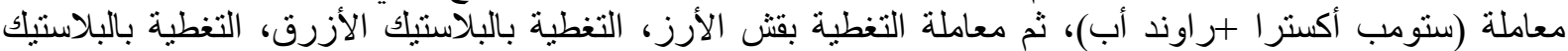

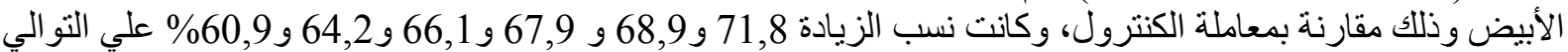

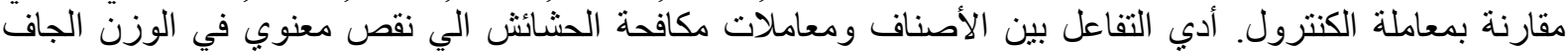

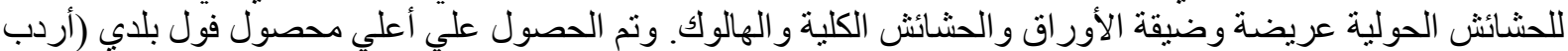

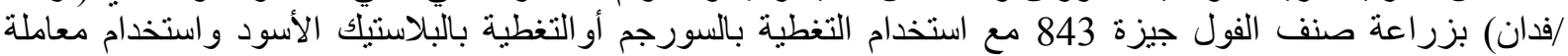

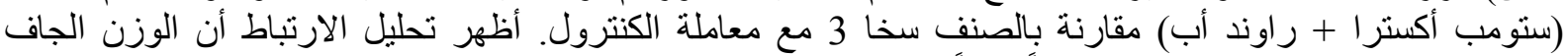

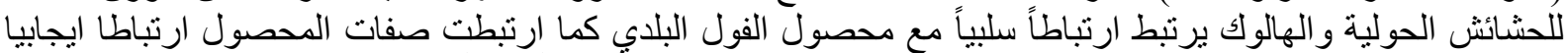

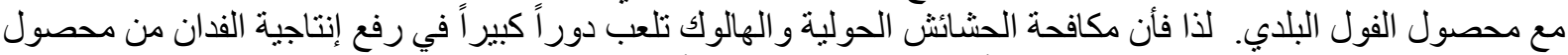

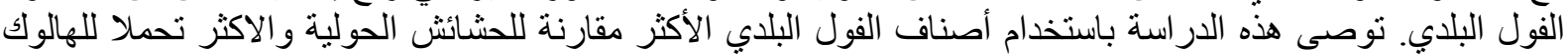

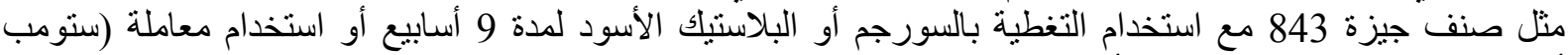

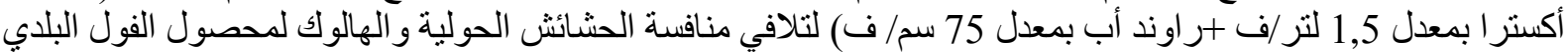
و بالتالي تحسين إنتاجية الفول البلاي.
\end{abstract}

المجلة العلمية لكلية الزراعة - جامعة القاهرة- المجلد (71) العدد الرابع، اكتوبر (2020): 251-263. 